\title{
The Shattered Glass. Shakespeare's Richard II and the Crisis of Hermeneutics
}

\author{
Jean-Marc Chadelat \\ Sorbonne University \\ Paris, France
}

For now we see through a glass darkly; but then face to face: now I know in part; but then shall I know even as also I am known.

\section{Corinthians 13: 12}

My purpose in this paper is to focus on one of Shakespeare's most poetic and enigmatic plays to consider the possibility that the dialectics of plurality and unity constitutes a major aspect of Richard II depending on the vision chosen by the spectator or the reader. I will also make the assumption that the art of interpretation is not immune to historical change, a fact that the play purports to represent in allegorical manner and with tragic overtones. The critical transition from a unitary to a pluralistic conception of the visible world which I believe the play is mainly about may well serve as an interpretive clue to approach Richard II as a tragedy of hermeneutics acting out an equation of human history with an entropic process generating an increasing sense of social separateness and mutual incomprehension. ${ }^{1}$ Like his contemporaries Shakespeare believed that history should/could teach moral and political lessons relevant for the present time. In this perspective, the sense of loss which sounds everywhere in the play cannot be ignored or underestimated. It is probably not fortuitous in this respect that a play scrutinizing the power of words and the role of tongue from so many angles leaves the spectator with the unsettling impression that language is "the greatest loser in the political power game". ${ }^{2}$ At the end of this ambiguous work, however caused, England, saved from economic bankruptcy by the change of regime, has nevertheless fallen into moral bankruptcy of a worse kind boding ill for the future ${ }^{3}$.

As a starting point I would like to question the foundations of an opinion shared, to a varying extent, by all commentators of the play. By this I mean the critical perspective which sees the play as - not exclusively but inescapably a political work staging a struggle for power and exposing diverging or opposed conceptions of government. ${ }^{4}$ Before I state my case, I will briefly survey the various readings illustrating this paradigm and highlight the fact that even the most contradictory presentations of Richard II come under the same interpretive category. Whether one perceives Richard as an indecisive "weak tyrant" or as an ineffectual kingly poet, it is the exercise of power and its attendant responsibilities that provide the yardstick with which his speeches and his behavior are to be gauged. In a similar manner, the contrasting interpretations deciphering the rebel as a subject revolted by injustice or as an ambitious rival of the king waiting to have his day rest on the same conviction, ie that Bolingbroke is a politician contemplating power as a means to mete out justice and inflict punishment or as an end which justifies the conquest of England and the eviction of his predecessor. To challenge a self-evident presupposition calls for a refutation in due form which may offer a manner of justification: I will try to comply after I have clarified what I mean by political then proceed to identify the roots of the disruption and the fruits of the conflict represented in the play. An objective assessment of the historical dimension of Richard II cannot be dissociated from the tragic quality manifested by the title of the successive quartos published between 1597 and $1634^{5}$. Nor can it be separated from the central notion of perspective which Shakespeare subtly integrates in the plot under the guise of poetic language.

\footnotetext{
${ }^{1}$ Charles Forker (ed.), King Richard II, The Arden Shakespeare, London: Thomson Learning, 2002, 34, 82-3.

2 Andrew Gurr, "The Unbalanced Richard II", in Richard II de William Shakespeare. Une ouvre en contexte, Caen: Presses Universitaires de Caen, 2005, 68-9.

${ }^{3}$ Paul M. Cubeta, "Introduction", in Paul M. Cubeta (ed.), Twentieth Century Interpretations of Richard II. A Collection of Critical Essays, Englewood Cliffs, NJ: Prentice-Hall, Inc., 1971, 5.

${ }^{4}$ Charles Forker, ibidem, 16-23, 90; Stanley Wells (ed.), King Richard II, The New Penguin Shakespeare, Harmondsworth: Penguin Books Ltd, 1997 [1969], 14.

${ }^{5}$ Andrew Gurr, King Richard II, The New Cambridge Shakespeare, Cambridge: Cambridge University Press, 1990 [1984], xiii. 
What is actually hinted at on several occasions is that the right (political) angle is likely to give a rather distorted perspective of the confrontation of characters and the meaning of facts as we observe the predictable dethronement of a disgraced king whose shameful behavior is bound to cause his ruin and his demise. To put it bluntly, the dubious legitimacy of the succession and the political ambivalence of the text do not afford the spectators and the readers a correct or coherent understanding of a tragic catastrophe presented through Richard's speeches as no less than a debasement of divine right and through Bolingbroke's action or his allies' pleas as no more than the redress of political wrongs. Whether we regard the play as being mainly concerned with the problem of tyranny and the best course of action for those who are subjected to it or as a dramatic work where the politic vein is mostly the pretext of a poetic elaboration on the part of a playwright who was inspired above all by the principle of balance and the nature of language, one cannot but feel that our experience of Richard II - on stage or on page - far exceeds an apprehension of the plot enunciated in political and/or poetic terms. The plausible reason for this insuperable discrepancy between form and meaning lies in the unavoidable impression that the many obscurities or "loose ends", of the play are not on the whole irrelevant to the problem of interpretation so that they need not be explained away but on the contrary originate from our blurred vision of things which seem out of perspective and deprive us of the true picture. The poetics of the play consistently suggests that there is much more than meets the eye or reaches the ear in the personal tragedy of Richard II, unfolding as it does against a backdrop of tacit resentment and explicit frustrations. In sonnet 24, which might have been composed in the 1590s, at about the same time as Richard II, Shakespeare extolls the beauty of the young aristocrat to whom the narrator is bound by passionate love and expounds on the artistic representation of an object that must be seen from a specific angle in order to have access to the true picture: "And perspective, it is best painter's art; / For through the painter must you see his skill / To find where your true image pictured lies, / Which in my bosom's shop is hanging still, / That hath his windows glazèd with thine eyes."7 The word 'perspective' has of course two different meanings here but the notion that the best vision of a work of art supposes to look at it through the poet's eye is prevalent in these lines.

This paper aims to discern the 'true image' lying in a play where the audience is constantly reminded of the necessity to see the meaningful picture through the playwright and assume that the vision of reality is deceptively simple. As a matter of fact the predictable disruption affecting the political sphere and the concomitant "failure of language to match reality" ${ }^{\prime \prime}$ are suggestively correlated by Shakespeare with the substitution of a mode of cognition for another on which the meaning of the play ultimately depends. Unless we find the adequate perspective enabling us to reconfigure what we see and hear into a recognizable pattern, neither plot nor play can be motivated and meaningful in a satisfactory way. A discernible consequence of this change of paradigms identified by Shakespeare as the distinctive feature of the intellectual revolution underlying the transition from the late medieval era to the early-modern time - is the emergence of a self-sufficient political order which redefines the conditions and the purposes of the exercise of power and has a decisive impact on the interpretation of history as well as the history of interpretation ${ }^{9}$.

\section{Richard II and the political perspective: self-evident truth or problematic postulate?}

If politics is defined as the organization and exercise of power in an ordered society or as the administration of a state, no serious difficulty arises to prevent the reader from proposing a seemingly coherent political interpretation of the play. Starting from an analysis of the dramatic interaction of the various characters and an overview of the historical background (more often than not dealing with the time of composition rather than the late 14th century), most (political) studies of Richard II delineate psychological profiles and infer plausible motivations which point up a tragedy of power politics, a story of "high politics" whose protagonist is "self-centred in imagination". ${ }^{10}$ Yet this association of power with politics, underscored as it is by an ideological approach, is much more than a mere synonymous propinquity sanctioned by use. As a matter of fact, the word power conveys the idea of corporal capability or physical strength, particularly in the sense of a material force which is manifested and asserts itself through external means.

\footnotetext{
${ }^{6}$ Kristian Smidt, Unconformities in Shakespeare's History Plays, London: Macmillan, 1982, 92.

${ }^{7}$ Katherine Duncan-Jones (ed.), Shakespeare's Sonnets, London: Bloombury Methuen Drama, 2018, sonnet $24,1.4-8,159$.

${ }^{8}$ Andrew Gurr, King Richard II, op. cit., 34.

${ }^{9}$ Derek Traversi, "Richard II", in Paul M. Cubeta (ed.), Twentieth Century Interpretations of Richard II. A Collection of Critical Essays, Englewood Cliffs, NJ: Prentice-Hall, Inc., 1971, 41.

${ }^{10}$ John Palmer, "Richard of Bordeaux", in Political Characters of Shakespeare, London: Macmillan, $1945,118,179$.
} 
Such is by definition the substance of temporal power which constitutes royal prerogatives and executive functions. Kingly power thus refers to all aspects of government proper even when political institutions do not take the specific form of a monarchy. The initial scenes of Richard II show for instance that the government of the realm is incumbent on the aristocracy as the sentence of exile against Mowbray and Bolingbroke is rendered by a council of peers where the king appears first of all as an arbiter. The unfolding of the drama reveals a significant transfer of power from the nobility as a whole, considered as a decentralized governing body subject to traditional rules, to an embryonic monarch enforcing a centralized regulation of the kingdom on his own initiative. ${ }^{11}$ Thereby can be seen more clearly the equivalence already mentioned between royal prerogatives and temporal power in the light of which the disconcerting behavior of Richard and the discordance between his attributions and his inaction may appear in a novel perspective and expose an unsuspected feature of his personality. In order to complete these terminological preliminaries, I should like to add that the governing function is twofold as it were: administrative on the one hand and defensive on the other, its main purpose being to ensure the administration of justice within the boundaries of the realm and the military defense of the kingdom against outside aggressions.

The problem raised by a comprehensive political apprehension of Richard II lies above all in the fact that such a reading presupposes the homogeneous nature of the two halves of the play, before and after the rebellious insubordination of Bolingbroke, taking at once the ideological mirror to reflect a variable message and provide an invariable code to decipher its meaning. In short and from a historical as well as hermeneutic viewpoint, the premise of this interpretive paradigm is to suppose the historical constancy of political stakes and rule out the possibility of a theoretical rupture affecting the conception of power and the place of politics as shown in the play. If the art of critical questioning relies to some extent on the ability to wonder at propositions and assumptions that common sense takes for granted, then suffice it to say that the widely assumed political nature of Richard II is problematic to anyone looking for an answer to the many questions raised by the text. ${ }^{12}$ Thence the following quandary: by referring the doubtful transfer of power from the king to the rebel to a mere political transition does not one tacitly apply to the Ricardian order the same set of ideological values and critical norms that the disruptive action of the Lancastrian party succeeds in imposing as the outcome of a process of drastic change? In order to establish the right diagnosis of the disease affecting the kingdom, would it not be desirable to effectuate a complete change of perspective by virtue of which the political symptoms of the struggle fade into the background and reveal another dramatic syndrome pointing to the prehistory and advent of politics? Seen from such a decentred angle, Richard II has only the deceptive semblance of a political play. The central opposition on which the argument of the play hinges is played out in a remarkably static fashion devoid of unexpected developments: as soon as Bolingbroke is back from exile "in braving arms" $(2.3 .112),{ }^{13}$ the conclusion is more than predictable and the action becomes mechanical as if some unseen spring were being steadily released without offering any control to the main two characters ${ }^{14}$. In a play where the ominous shadow of what is not revealed is constantly hanging over the partial exposition of facts, the stage falls short of displaying Bolingbroke's antagonism towards Richard as an avowed conflict between sworn enemies or political rivals. ${ }^{15}$ The usurper eventually conquers the realm and the throne without a prior declaration of war or general proclamation which could endow his engagement with an assumed ideological significance.

\footnotetext{
${ }^{11}$ Irving Ribner, "The Historical Richard", in Paul M. Cubeta (ed.), Twentieth Century Interpretations of Richard II, Englewood Cliffs, NJ: Prentice-Hall, 1971, 13.

${ }^{12}$ Peter Ure (ed.), King Richard II, The Arden Shakespeare, London: Methuen, 1956, 1xiii, lxxxiii; Allan Bloom, "Richard II", in John Alvis \& Thomas West (eds.), Shakespeare as Political Thinker, Durham: Carolina Academic Press, 1981, 51-61, 51-2 note 1; Louise Cowan, "God Will Save the King: Shakespeare's Richard II", in John Alvis \& Thomas West (eds.), ibidem, 63-4.

${ }_{14}^{13}$ All references to the text of the play are to Forker's edition.

${ }^{14}$ The efficiency of a power beyond the characters' volition (notably Bolingbroke's) has been truly remarked by John D. Wilson in the introduction to his New Cambridge edition of the play (Cambridge, 1939), whereas the "formal and ceremonial" dimension of Richard II, a play depicting a "world where means matter more than ends, where it is more important to keep strictly the rules of an elaborate game than either to win or lose it", has been pointed out by E. M. W. Tillyard, "Richard II", in Paul M. Cubeta (ed.), Twentieth Century Interpretations of Richard II, Englewood Cliffs, NJ: Prentice-Hall, 1971, 15, 20.

${ }^{15}$ Brents Stirling, Unity in Shakespearean Tragedy. The Interplay of Theme and Character, New York: Columbia, 1956, 379.
} 
All that can be logically presumed of his motives in view of his deeds is never borne out by the text, corroborated by his words or substantiated by any choric character. He performs ceaselessly yet never discloses what motivates his illegal return from banishment, the English campaign he surreptitiously and hastily embarks upon, the punitive ride into which he throws himself headlong to fight Glendower in the Welsh marches of the kingdom and the seizure of a crown which does not belong to him by right. Nor does he unveil his objectives. In a play conspicuously lacking in monologues (with the exception of Richard's soliloquy in his prison), the rebel's laconic speeches following his military landing is, to say the least, puzzling. ${ }^{16}$ Bolingbroke's taciturnity is all the more perplexing in that, unlike the "silent King" (4.1.290) he is, who constantly refrains from speaking his mind, Richard is eloquent even to the point of verbosity at times. However, if we pay attention to the gist of what he is saying, the legitimate king hardly ever shows himself in a political light. He never makes any allusion to a collective project or personal ambition. Trying desperately to make sense of what is happening to him, he finds solace in his plight and alternately sinks into despair as his mind drifts from one digression to another, revealing as much self-assurance as credulity. Yet one would be hard put to discern in his lyrical effusions or his disconnected acts the outline of a conscious policy or strategic designs of any kind. Supposing however that the king of England works towards hidden ends, the paradox would obviously be that his politics is utterly lacking in willpower and determination, Richard's problem in the play being essentially his inability to exercise power by means of an actual domination imposed on his vassals. ${ }^{17}$ In connection with this executive powerlessness, it is probably no coincidence that Shakespeare has attributed to his protagonist a purely verbal conception of authority which highlights the function of language in the play and focuses in particular on the bond uniting signs and reality. ${ }^{18}$ Conversely, Bolingbroke appears throughout the play as the ostentatious holder of effective power which he employs unhesitatingly and unscrupulously before his coronation while he merely intimidates Richard into submission without any bloodshed or battle. The psychological subjugation of Richard's spirit represented in a striking context of military and judicial asymmetry (departing from what Shakespeare found in his main sources) ${ }^{19}$ precludes a coherent ideological reading of the king and deflects the critical investigation toward the identification of a yet undisclosed interpretive configuration.

The unrealistic dramatization of the Lancastrian victory and Ricardian defeat is conducive to a hermeneutic conversion inciting one to examine the dramatic evidence on an analogical level and search for a latent meaning of the emblematic confrontation. Two avenues of approach seem apposite. We could question analytically the role and place of religion in the play to determine the differences between the theological beliefs of Richard (and his faithful supporters) and the secular convictions of a new kind that we perceive within Lancastrian ranks. Legitimate as it is, this approach would probably overemphasize the static construction of Richard II with the suggestion that its dramatic development is subservient to abstract conceptions and disembodied characters. This is mainly why I will circumscribe the issue of unity and plurality in the play from a historical viewpoint and propose an explanation which is congruous with a dynamic apprehension of the momentous revolution enacted on stage. Seen from an oblique perspective bringing to the fore a necessary change of interpretive standards, the clash between defective values and traditional beliefs is what sums up the disruption represented by Shakespeare.$^{20}$ Considering history not only as a thematic source or illustrative backdrop but chiefly as an object of enquiry, the dramatic form that takes shape when "eyed awry" (2.2.19) uncovers the emergence of an autonomous political sphere (as we still know it today) breaking away from the theological focus it was revolving around until that decisive moment. According to this view, the Lancastrian rejection of the superiority of a theoretical conception endorsed by a discredited Richard corresponds to the tragic dislocation of a heteronomous order anchored in the religious sphere and replaced by a modernized organization where political autonomy functions as a foundation stone and a driving force. The rebels' implicit dismissal of the subordination of political power to religious law is the source of Richard's incomprehension of Bolingbroke who will not listen for his part to the normative words and theological assertions of the king and his followers.

\footnotetext{
${ }^{16}$ Brents Stirling, "Bolingbroke's 'decision”, Shakespeare Quarterly, n 2, 1951, 27-34, 34; Peter Ure, (ed.), King Richard II, op. cit., lxxii-v.

${ }^{17}$ Peter Ure, ibidem, lxxi.

${ }^{18}$ Leonard F. Dean, "From Richard II to Henry V: A Closer View", in Paul M. Cubeta (ed.), ibidem, 61.

${ }^{19}$ Richard Hosley (ed.), Shakespeare's Holinshed, New York: Capricorn Books, 1968, 60-97.

${ }^{20}$ E. M. W. Tillyard, Shakespeare's History Plays, Harmondsworth: Penguin Books Ltd, 1964 [1944], 259; Alvin B. Kernan, "The Henriad: Shakespeare's Major History Plays", in Alvin B. Keenan (ed.), Modern Shakespearean Criticism. Essays on Style, Dramaturgy, and the Major Plays, New York: Harcourt, Brace \& World, Inc., 1970, 245-75.
} 


\section{The painful transition from heteronomy to autonomy: from heaven-sent laws to self-governing communities}

The pervasive language barrier that prevents the king and the rebel from understanding each other and makes incommunicability a prominent theme of the play is rendered particularly meaningful in the light of the semiotic revolution imposed on the kingdom by Bolingbroke's action. ${ }^{21}$ The new socio-political pattern emerging in the wake of his reforms gives rise to a reflexive type of discourse disowning the symbolic apprehension of the world and the essentialist creed which Richard, Carlisle, John of Gaunt and Edmund of Langley strove to preserve. ${ }^{22}$ In correlation with the implicit promotion of politics and change in the course of human history, we witness the appearance of ideology whose primary dramatic function is to justify in the eyes of the spectators what is utterly indefensible according to the traditional doctrine. A major outcome of the removal of the political sphere from its theological orbit is eventually to separate the trajectories of political action and theological vision which will henceforth follow independent courses. The focus put on the change of regime by the very structure of the play foregrounds the decisive impact of a revolution in thought affecting simultaneously the destiny of political power breaking free from external norms and that of religious beliefs which nevertheless persist on a more personal level. Once again, a dialectical approach is most convenient to discern what the inchoate political body owes to the persistency of religious beliefs and, conversely, to what extent the theological dogma interferes with a liberated sphere of power.

The primary feature of this substitution of mental attitudes and executive practices as we see it happening after Bolingbroke's return from exile finds expression in a redirection of legitimate time from the past to the future. The theological faith shared by Richard and his uncles, just to mention a few, is rooted in the authority of the past. In his textbook praise glorifying the virtues of a blessed kingdom, the dying Duke of Lancaster laments the selfinflicted conquest of England and disparagingly compares Richard's indignity with the gallantry of his illustrious predecessors (2.1.40-66). It is worth noting though that the duke blames the king's failure not on his inability to attain political or military goals but on his moral incapacity to emulate his glorious lineage. ${ }^{23}$ The rhetoric of frustration underlying John of Gaunt's speech on his deathbed exposes the intricate relation between his pastoriented outlook and his ethical censure of the king's transgressive behavior. The shame putting a blot on the realm due to Richard's confusion of his kingdom with an ordinary estate is to be assessed by contrast with his progenitors' honorable conduct for want of contemporary norms in political matters. Similarly, the Duke of York's reproof of Richard's seizure of Bolingbroke's inheritance is an indirect condemnation of Richard's inaction and improvidence. However, the future regent of England does not rebuke the king for political innovations resulting from his rash behavior. On the contrary, York finds fault with Richard for his inability to maintain the age-old coherence of the realm in the name of a timeless conception of England underscored by his reference to immutable ethics. Both his unfavorable comparison of Richard with the Black Prince his father and his admonition following the king's violation of "Hereford's rights" (2.1.195) refer to a sacrosanct order received from supernatural powers that temporal agents do not have authority to adjust to changeable conditions or even try to improve. The ascendancy of religious beliefs over the upholders of tradition precisely consists in the fact that all these men refuse to lay down new rules or transform the extant norms whereby power is exercised just as they trace back its origins to a primeval time beyond human reach.

The heteronomous foundations which support Richard's system of representations and beliefs (notwithstanding his flawed comprehension of them) shape the organization of the polity and dissuade anyone from attempting to challenge this substructure or bring significant changes to the social architecture erected on it. Richard and his uncles share with the bishop of Carlisle the same certainty that the natural law applicable to every subject in the realm (regardless of his rank or station in life) is not liable to any form of deliberate alteration that might turn out to be more detrimental than beneficial. ${ }^{24}$

\footnotetext{
${ }^{21}$ Peter Ure (ed.), King Richard II, op. cit., lxxx; Joan Webber, "The Renewal of the King's Symbolic Role: From Richard II to Henry V', Texas Studies in Literature and Language $\mathrm{n}^{\circ}$ 4, 1963, 530-8; Joseph A. Porter, The Drama of Speech Acts: Shakespeare's Lancastrian Tetralogy, Berkeley, CA: University of California Press, 1979, 11-51.

${ }^{22}$ Allan Bloom, "Richard II", in John Alvis \& Thomas West (eds.), ibidem, 56.

${ }^{23}$ Alexander Leggatt, Shakespeare's Political Drama. The History Plays and the Roman Plays, London and New York: Routledge, 1988, 56-7.

${ }^{24}$ Idem, 60 .

92
} 
The accepted subjection to a legislative power originating from above and from which both rulers and ruled alike derive their rights and most of their duties is what circumscribes heteronomy. Simultaneously invisible in that its causes and influence are hidden from sight yet manifested by the unmistakable consequences of its observance or disregard, this other-worldly law sustains in various modes the common faith of the defenders of the traditional order. The accusations levelled at the king by his benevolent counsellors and caring guardians, who exhort him to amend his ways and denounce the royal confusion between political realities and religious principles, do not question the indisputable primacy of this superior legislative source. Despite their differences of opinion with the king and their idiosyncratic personalities, all these men do not feel responsible for the worldly order of things. The bishop of Carlisle as well as Richard or the Duke of Aumerle know themselves to be (unlike the rebels) the inheritors of an organization of the earthly city upon which they should have no influence whatsoever by virtue of the absolute necessity for its transcendent foundations to prevail at all times over human discretion and volition. ${ }^{25}$

In parallel with this representation of origins, heteronomy is refracted into an order of power (as distinct from a political order) on top of which the king reigns supreme. The temporal function of regulating and defending the community falls to a caste of professional warriors whose impatience and boisterousness are exhibited from the outset of the drama. Inherent to the feudal kingship represented in the initial scenes is an aristocratic distribution of power which, though setting apart a crowned sovereign from his peers, nevertheless relies on the plurality of its holders and its collegial exercise whenever the matters to be settled concern the kingdom as a whole. Whatever we may think of Richard's blatant inadequacies and thoughtless acts, the judicial verdict he returns following the deliberation of the royal council bears witness to a collective exercise of power that the Lancastrian party will gradually concentrate into their hands as a prefiguration of the centralized monarchy to come. However, Richard is a consecrated king who never fails to harp on the virtues of his coronation. The redundant evocation of Richard's sacredness (by himself and his believers) throughout the play (until the pathetic episode when he questions his very identity) underlines the incarnation in the king's person of a legitimizing principle of supernatural origin. Filled with and enthused by the mystery of divine presence (a presence that Richard desperately scrutinizes in the hope of discerning its visible signs), the king of England is presented by Shakespeare as the mediator between heaven and earth who tragically fails to keep the peaceful order and unfailing justice for the preservation of which his royal initiation has provided him with the adequate knowledge and spiritual comfort.

The immemorial foundations of the heteronomous order are also reflected in a social pattern at once holistic and hierarchic. The network of mutual obligations and exchange of reciprocal services which define the feudal system apply to Richard's England. ${ }^{26}$ Social relationships are of a personal kind and the homage sworn by vassals to their overlord is a symbolic gesture of binding force which is guaranteed by the sacramental inviolability of public oaths. In the opening scenes all the characters mention these customary ties and constraining bonds to which they are subjected by consent as the social expression of unequal natural dispositions and dissimilar social functions. All of them value the observance of solemn oaths as a sacred duty and a pillar of social stability. Richard's uncles never miss an opportunity to reassert the necessary link connecting the hierarchic structure of the kingdom and the unshakeable faith of the whole community in its intangible principles. When he faces up to his nephew as regent of the realm, the Duke of York indirectly denounces the selfish motives of a wronged subject who comes in arms against his sovereign and his motherland "Frighting her paled-faced villages with war" (2.3.94). Later on, just before Richard is publicly dethroned, Carlisle accuses the rebels of sowing disorder and strife, warning them that Richard's unnatural deposition is bound to unleash violence, divide the polity and eventually ruin feudalism $^{27}$ (4.1.137-50). The holistic vision of the proponents of hierarchy offers a comprehensive approach to social order and is just the opposite of the pluralistic perception of a community in progress that the Lancastrian leader gradually imposes in minds as in deed to his advantage and that of his associates. ${ }^{28}$

\section{From the theological apprehension of Creation to the ideological justification of its transformation}

The political beliefs that rise on the horizon of the rebellion can be defined as an inverted faith in the authority of the future.

\footnotetext{
${ }^{25}$ Louise Cowan, “God Will Save the King: Shakespeare's Richard II”, in John Alvis \& Thomas West (eds.), ibidem, 69.

${ }^{26}$ Stanley Wells (ed.), ibidem, 39.

${ }^{27}$ Louise Cowan, "God Will Save the King: Shakespeare's Richard II', in John Alvis \& Thomas West (eds.), ibidem, 70-1.

${ }^{28}$ Janette Dillon, Shakespeare and the Solitary Man, Totowa, NJ: Rowman \& Littlefield, 1981, 73-5.
} 
The autonomous order that the rebels bring into being through coercive action is inseparable from a futureoriented attitude relying on the effectiveness of historical progress. Not that, unlike the traditional order, the incipient self-ruling community is assumed to monopolize the awareness of historical change and the subsequent necessity for conflicting propositions and interpretations. The political roots of the revolution precipitated by the rebels is rather to be found in their claim to appropriate the unrestricted capacity for collective self-transformation which leads to renovate society and redefine the standards whereby power is exercised as an intentional step towards self-rule. By drawing a parallel between the rebels' efficiency and the king's inertia from a political perspective and applying the same interpretive criteria to both sides, we clearly misconstrue the symbolic meaning of an allegorical conflict ${ }^{29}$ and overlook the semiotic dimension of the Lancastrian revolution. For in effect the political disruption brought about by the rebellion resides in the progressive revelation of the potentially creative nature of time allowing a regenerated body politic to modify itself and change its environment. The novel awareness of the productive force of evolution exerted on oneself by a forward-looking community is what inspires Bolingbroke's supporters even before their champion breaks his vow and returns to England with an army.

The concerted project of invasion evoked by the Earl of Northumberland at the end of Scene 1, Act 2 discloses the motivational forces behind the conspirators' revolutionary confidence in historical progress. Opposing suicidal apathy and self-destroying passiveness to their sense of responsibility and the urgent need to react to the current state of affairs, the three men turn their attention toward the future and encourage each other to work out a collective response which is likely to fulfil their expectations and get them back in the saddle for military action. Reproaching themselves vehemently with "suffering so the causes of our wrack" (2.1.269), they pay religious attention to Northumberland who paints to them in glowing colors the prospects of a bright future (2.1.270-2). For want of a clear line of conduct prescribed by unchangeable principles on account of their superhuman source, the three defectors stir themselves into action by means of a contingency plan which claims to draw its inspiration from the timeliness and appropriateness of change. Unlike the king's uncles who placed their energy in the conservation of a precious legacy and blamed Richard's deafness to good counsel on his lack of good sense and prudence $^{30}$, the three plotters deliberately engage in the conversion of the kingdom along ideological lines, assessing themselves the necessary changes they advocate (2.1.291-2). The convergence of common aspirations and commitment to the same cause which bind the rebels together find expression in a tacit partnership set up with the idea of advancing society and promoting its improvement. The implicit requirement is that all individual or collective activities within the community must be organized in relation to the near future as the temporal realm of prospective results and anticipated benefits.

The thorough change of temporal orientation is accompanied by a concurrent renovation of society. The leading motive behind the hoped-for renaissance of a declining community is that its regulating members should enjoy exclusive mastery over it. In the mental context of the traditional order, the hierarchic structure of society and conservative transmission of values to be passed on intact to the next generation assigned everyone to a preordained function and specific role in accordance with their peculiar calling and indefeasible norms. Contrastingly, the rebellion brings about a reversal in depth affecting the sacramental nature of social relations as well as the individual identity of political players. ${ }^{31}$ In the socio-political world of Bolingbroke as portrayed by Shakespeare in an incomplete form, nobody can be certain of his office. The transformation outlined in the wake of the usurpation gathers momentum in the successive plays of the two tetralogies to the conclusive Henry VIII where the autocratic monarch bestows honors and titles on obedient favorites and right-hand men to suit his pleasure and interests ${ }^{32}$. In Richard II, the Earl of Northumberland embodies the social promotion of these new men whose destiny is closely bound to that of the rebellion. As Bolingbroke's factotum and henchman, his function in the play is mainly executive just as his perception of the world is operative and self-interested.

\footnotetext{
${ }^{29}$ Louise Cowan, "God Will Save the King: Shakespeare's Richard II", in John Alvis \& Thomas West (eds.), ibidem, 78-9.

${ }^{30}$ Alexander Leggatt, ibidem, 55.

${ }^{31}$ Philip Edwards, "Person and Office in Shakespeare's Plays", Proceedings of the British Academy, $\mathrm{n}^{\circ}$ 56, 1970, 93-109; Frank W. Brownlow, Two Shakespearean Sequences: "Henry VI" to "Richard II" and "Pericles" to "Timon of Athens", Pittsburgh: University of Pittsburgh Press, 1977, 95-111.

${ }^{32}$ John Margeson (ed.), King Henry VIII, The New Cambridge Shakespeare, Cambridge: Cambridge University Press, 1990, 33-5.
} 
He asserts the presence of his master whenever Bolingbroke does not want to expose himself by tarnishing his image or diminishing his credit, acts as an emissary to Richard and a mouthpiece for the rebels when he demands that the king should read an indictment of his "grievous crimes" (4.1.223) in order to persuade public opinion of the legality of the deposition. ${ }^{33}$

Significantly, the unscrupulous utilitarianism of the Earl of Northumberland points to a debasement of feudal man-to-man relations into a pattern marked by increasing venality and flagrant hypocrisy. The contrast between the sycophantic, obsequious attitude of the servants of the new regime and Richard's favorites indirectly accused of being shameless flatterers and evil counsellors (in spite of what we see and hear on stage) ${ }^{34}$ is all the more striking when Bolingbroke is in the company of his political sympathizers. On the way to Berkeley castle, Northumberland rides alongside his new master and offers a promising glimpse of the renewed ethos of Lancastrian courtiers (2.3.6-18). Bolingbroke is not taken in by such an ingratiating speech: "Of much less value is my company/Than your good words" (2.3.19-20). Yet, the art of fawning in which Northumberland indulges with remarkable zeal becomes the rule. The semiotic deterioration evinced by this benign episode symbolically points to the evocative substitution of regular toadying for ritual courtesy. In a suggestive way, another aspect indirectly connected to this change of social code is the openly materialistic mood prevailing in the business transactions between Bolingbroke and his allies. To the impoverished rebel, not as yet in possession of his dukedom and revenues, his expression of gratitude to his supporters is "the exchequer of the poor" (2.3.65). But his adventurous life on credit does not rule out acknowledgements of a political debt (2.3.59-62). In this revealing declaration as in the last scene of Act $\mathrm{V}$, Bolingbroke promises rewards in return for the loyalty of his renewed subjects. A manner as it were to establish a monarchical system of venal allegiances and obtain his accomplices' gratefulness in exchange for political favors.

\section{Religious ethics in the service of an ideological project: factor of political order and historical fulfillment of the community}

The projection into the future which commands present action requires an explanation at once demonstrating the rightness of political decisions and adducing adequate grounds for observable conducts. It presupposes also that the image of the future be outlined so that collective energy may be summoned up with maximum effect. Lastly, it necessitates an interpretation of the past. These new demands emerging in the wake of self-government approximately define what could be referred to as an ideological discourse. With the advent of an autonomous political order, the audience witnesses the appearance of a new doctrinal apprehension of society dealing with current changes and positing beliefs of a political nature which take the place of the "law and form and due proportion" (3.4.41) previously accepted as an intangible model for the kingdom. ${ }^{35}$ An essential aspect of this historical substitution of ideological convictions for theological principles is the justification of the conscious process set in motion by the rebels. By justification it should be understood in the first place the exposition of motives which vindicate the forcible correction of royal abuse and supply moral as well as legal grounds for this show of strength. At every stage of his progression to the throne (whether it is premeditated or not is another matter which can hardly be cleared up in view of the sole text) ${ }^{36}$ the rebel is careful to warrant his judicial and military initiatives with a semblance of lawfulness which may appeal to the sympathy of the audience and exonerate him from any personal responsibility in the overthrow of Richard. From a philosophical and historical angle, we may detect in Bolingbroke's cautious distance and irresponsible claim the rise of an impersonal crown that will assert itself in the successive plays of the second tetralogy and steadily impose a relentless domination on reluctant populations, particularly in the judicial and military spheres. As a symbolic attribute of sovereignty turned into a theatrical prop by the defeated king, the crown is on the way to becoming a legal abstraction in the name of which Richard's successors will rule England for the safeguard and build-up of a disembodied state.

The vindication of what is undertaken by the Lancastrian party also takes the form of a reflexive discourse of the community on itself intending to account for the forces which impart its impetus to the dynamic process of change.

\footnotetext{
${ }^{33}$ Louise Cowan, "God Will Save the King: Shakespeare's Richard II", in John Alvis \& Thomas West (eds.), ibidem, 79.

${ }^{34}$ Paul Gaudet, "The 'Parasitical' Counsellors in Shakespeare's Richard II: a Problem in Dramatic Interpretation", Shakespeare Quarterly, $\mathrm{n}^{\circ}$ 33, 1982, 142-54; Charles Forker, ibidem, 30, 47.

${ }^{35}$ Paul M. Cubeta, "Introduction", in Paul M. Cubeta (ed.), ibidem, 11.

${ }^{36}$ Charles Forker, ibidem, 26-9.
} 
This dimension includes a sketchy portrayal of the future commonwealth and the motivating promise of foreseeable realization. Although Bolingbroke remains silent on this, refusing to divulge the final objective he hopes to attain just as he does not provide any understanding of his inner feelings, his supporters offer an insight into this new conception of society and history. At the end of the episode when Northumberland announces the impending return of his champion in an undertone of conspiracy, a certain vision of the future takes shapes with the avowed intention to regenerate the kingdom so that "high majesty look like itself" (2.1.295). The comprehensive motive put forward by one of the most ardent supporters of Bolingbroke functions as a cause and an objective. His belief in a better future is inseparable of his determination to restore a supposedly degenerated kingship. In fact, the break with the ancien régime achieved by the impatient nobles in the field of theory and practice leads to the institution of a new socio-political order without any possible comparison with the one they aim to rehabilitate. The following plays of the two tetralogies (in chronological order of the historical reigns) show that despite their claim to the contrary, a widening gulf is created by the rebels between the feudal system and allegorical vision characteristic of the medieval civilization they debunk and the defective early modern world associated to a down-to-earth apprehension of reality they promote by their action. ${ }^{37}$

The last feature of the Lancastrian revolution that I would like to investigate is the ideological light in which the instigators of change throw the past and its reconstruction. As mentioned earlier, the past has first and foremost a mythical value to Richard's uncles who personify a heroic age about to disappear with them. To these guardians of tradition in the full sense of the word, the past is less a bygone dimension of human experience or a "mirror for magistrates" where princes and their subjects should be looking into for lessons to be learned in the present than a temporal form of transcendence offering an archetypal image of the origin of societies and an unsurpassed model functioning as an ideal. On the contrary, Bolingbroke's implicit conception of history makes the near past a stake in the rebellious struggle and legitimization process he initiates. To a large extent, Richard's "tyranny" proceeds from an ideologically one-sided version making use of the king's inconsistencies and thoughtlessness to produce and propagate a biased interpretation of his failings. As most editions of the play testify, this partial apprehension of an allegedly despotic rule has been quite influential with audiences and it has dominated the critical scene for a long time. Despite the harmful credit enjoyed by this vision of the protagonist, I have no intention of adopting a pro-Ricardian stance to set things right: far from being the martyr of a just cause he seems to be at times, Richard makes repeated mistakes, does not take heed of the good advice dispensed to him and breaks the fundamental customs of the realm, ignoring the rules of succession entitling Bolingbroke to his dukedom. Nevertheless, I make my own Tillyard's judgment that Richard's absolutist rule and cruel oppression rest on insidious charges of questionable status more than on incontrovertible evidence of his wayward autocracy. ${ }^{38}$

The reading of the present instilled in individual consciences by the ideological intimation of the rebels is the prelude to a large scale operation of historiographic control carefully conducted by Bolingbroke-Henry IV and his son. The relation to the past thus becomes in Richard II a political dimension of the present which demands to be appropriately interpreted and requires particular surveillance from the crown. Throughout his military campaign in France, represented by Shakespeare as the climax of the eponymous play, Henry V does his best to suggest and enforce (on pain of death) an orthodox reading of the military and judicial events (including the most implausible outcome of the battle of Agincourt) that can fit his political interests and meet the expectations that his regime has aroused in the hearts and minds of his devout followers. ${ }^{39}$ The oriented presentation of the past resulting in an institutional reading of history offers a whole range of new attitudes to the political reformation in progress and exposes the chronicles of former times to reviewed judgments passed to justify a dubious policy or rehabilitate a controversial forerunner. These revisionist interpretations propounded by the official brand of history finally prefigure a crucial aspect of political ideologies that will be perceived with increasing clarity as the successive reigns unfold on stage. The explanatory justification of imperative transformations that ideologists working for the Crown irrigate with political beliefs in a better future or the need to reform a supposedly bankrupt order diversifies into several irreconcilable theories.

\footnotetext{
${ }^{37}$ Alvin B. Kernan, “The Henriad: Shakespeare's Major History Plays”, in Alvin B. Kernan (ed.), ibidem, 245-6.

${ }^{38}$ E. M. W. Tillyard, ibidem, 261.

${ }^{39}$ Harold C. Goddard, The Meaning of Shakespeare, 2 vol., Chicago and London: University of Chicago Press, 1960 [1951], vol. 1, 215-70; Andrew Gurr (ed.), King Henry V, The New Cambridge Shakespeare, Cambridge: Cambridge University Press, 1992, 6-16.
} 
An essential feature of the socio-political autonomy that we see in its early phase as the rebellion gains ground is to authorize a plurality of explanations of the past and several propositions for the future based on antinomic assumptions. In this respect, Richard II represents the last of a unitary view on the means and ends of collective action. As soon as Bolingbroke accedes to the throne, an all-pervading division of minds and hearts splits up the kingdom and sets apart contradictory convictions and competitive modes of action. ${ }^{40}$ The polycentric structure of the two parts of Henry $I V$, where the rebels, the courtiers and the tapsters belong to separate spheres and coexist with a limited understanding or acceptance of each other, is the symptom of a social and political break-up which an ideological discourse will make every endeavor to neutralize (at least verbally) by dint of the unlikely promise of restored unity. ${ }^{41}$

The profane hope in a future reconciliation that political ideologies inherit mostly from religious beliefs recycled to the advantage of secular rulers (a transfer of faith from the spiritual to the temporal which underlies the Lancastrian and Tudor myths) is nothing but the reverse side of a process stripping Richard's (and his uncles') theological statements of their integrative function and legitimizing authority. The separate courses followed by the two independent spheres signal a divergence of the corresponding functions which nevertheless continue to be under reciprocal influence. The interconnected ideological discourse and political practice borrow from the religious field the central theme of unity of the regenerated body politic. Formed around antagonistic political alliances and social factions, flourishing ideologies strive to subordinate collective action to the historical achievement of unity and unanimous submission to the state in a context of secularized eschatology. On the other hand, divine aspirations and theological tenets find themselves under the influence of a political doctrine and practice with which they are henceforth in competition for supremacy within a society no longer ordained by religious law. This crucial change takes on two complementary forms. In the first place, the socio-political regeneration of the kingdom compels the upholders of the traditional order, lest they should renounce their identity and be absorbed by the newfangled organization, to convert without further delay to the pragmatic methods used by their opponents and articulate their claims along the same ideological lines that they contest. The second notable aspect concerns the revision and understanding of dogmatic knowledge in a more individualistic and naturalistic direction: turning away from the supernatural foundations of traditional dictates as from the compelling sense of obligation inspiring every subject toward the kingdom and the king, the political community is from now on envisioned as a joint property available for private use and self-realization.

\section{Separate power and fragmented identity: from a successful usurpation to the difficulty of being oneself}

The application of an internal paradigm shift prompted by the unbalanced structure of the play and elusive personality of the protagonist further emphasizes the demise of the late medieval order giving way to an early modern state and giving up the speculative conception of the communal bond as the touchstone of universal values and fixed ideals. ${ }^{42}$

\footnotetext{
${ }^{40}$ Louise Cowan, "God Will Save the King: Shakespeare's Richard II", in John Alvis \& Thomas West (eds.), ibidem, 79. Although I fully agree with the statement that Richard II represents a "fall of nature and of England", showing that the "folk are no longer unified by a common purpose", I cannot subscribe however to the idea that the sequence of English plays presents a carefully worked out pattern taking the form of an "endless cycle of human action, repeated in time, with no apparent moral progress". This interpretation of Shakespeare's historical plays, relying as it does on the conviction that the "fundamental figure of history" to be found in them is "the move from order to chaos and back again to order" overlooks the fact that the two tetralogies enact a succession of historical cycles marked by a growing sense of instability and disharmony culminating in Henry VIII. While a delusive vision of this conclusive drama often suggests that its main theme is the longawaited restoration of order enforced by an efficient monarch so that England comes out as the real winner of the protracted struggle shown in the first tetralogy, I think that Henry VIII should be viewed essentially as representing the unrestricted supremacy of a political prince over theological tenets (on this see Bloom, "Richard II", in John Alvis \& Thomas West (eds.), ibidem, 58-60) and correlatively as a crucial stage along the road to a general extension of social disorder and ideological strife, inciting us to consider Julius Caesar and Coriolanus as dramatic sequels of the English plays. Seen in this entropic perspective, the "history of the English people" can hardly be envisioned as the mere theatrical repetition of the "story of mankind". The "second fall of cursed man" (3.4.76) evoked by the anguished Queen in the symbolic garden of Richard II is more than a metaphorical reminiscence of Adam's fall from grace, the context of the play inducing one to interpret it in a more pessimistic light as an additional fall aggravating the original sin and further alienating man from God.

${ }^{41}$ John Danby, Shakespeare's Doctrine of Nature: A Study of King Lear, London: Faber and Faber, 1949, 81-101.

${ }^{42}$ Alvis B. Kernan, “The Henriad: Shakespeare's Major History Plays”, in Alvin B. Kernan (ed.), ibidem, $250-4$.
} 
In accordance with this theoretical supremacy of the collective over the individual everyone felt indebted to all other members of the community and was likewise encouraged to go beyond the bounds of his particular interests and expand his social personality through daily intercourse with his unfamiliar fellow creatures. The relevance of an interpretive shift to uncover the scale of this historic and hermeneutic upheaval is adequately suggested by the fictitious scene in which Bushy tries to comfort the Queen and convince her that her tragic foreboding is groundless (2.2.14-33). As we are to realize though, Bushy's entangled explanation about the distorting power of grief and rational interpretation of the Queen's sorrow turn out to be misleading while the latter's intuitive sense of a "nameless woe" and intimate persuasion of some "unborn sorrow" are more than confirmed by forthcoming facts. Transposed on an ideological level, the spiritual communion and intellective clairvoyance evinced by the Queen (as by Richard, Carlisle and York in other circumstances) enhance the irreversible transition from a community of mutually obliged creatures to a body of associated members and temporary allies following a logical inversion which highlights the anomalous nature of the reversal. ${ }^{43}$

The paradox that I would like to mention as a conclusion is that, far from allowing its members to have a better command and understanding of themselves, the theoretical and practical regeneration of a community conceived from now on along organic lines as a comprehensive body where individuals combine into a more powerful entity favors all the uncertainties deriving from an unstable ideological language ${ }^{44}$ and insecure social identity that the sacred foundation and hallowed organization of the traditional order warded off. Unlike the Lancastrian society driven by perpetual movement and universal competitiveness where the appropriation of selfhood impels all members to keep to themselves in order to try to harmonize individual profit and collective purposes, the hierarchical structure inherited from a spiritual source and conforming to an invariable pattern used to preserve self-knowledge through the permanent risk of identity alteration incurred as everyone was exposed to frequent contact with outsiders and strangers. In giving precedence to pragmatism over principles (politics over ethics), the dissentient establishment of the Lancastrian order can be properly encapsulated as the dramatic emancipation of early modern communities from a theological hold and symbolic apprehension of the natural world considered to be obsolete by the promoters of a regenerated England. The encompassing crisis represented in the play thus shifts the emphasis of man's subjection to others and comprehension of himself from the macrocosm to the microcosm by raising the issue of the problematic development of personal identity and concurrent rise of modern subjectivity. ${ }^{45}$ Whereas Richard's trespasses were qualified according to sanctified rules providing everyone with the tranquil assurance of their necessity (for others as for themselves) the contrasting advent of an autonomous political order and arbitrary social code coincides with a general identity crisis which manifests itself through a ubiquitous feeling of contingency affecting all beings without exception. The predominant love of the earthly city and attendant reliance on human calculation underlying the alleged restoration of kingship are inseparable from an ontological anxiety and axiological relativism which become the hallmark of the new regime. The shattering of the looking-glass where the dispossessed king had caught a glimpse of his tormented soul and annihilated selfimage can be seen in this perspective as a theatrical gesture ushering in the age of interpretive ambiguity along with the delusion that demoted theological truths can be adequately superseded by fallible, subjective significance. ${ }^{46}$ The far-reaching revolution dramatized in Richard II is then appropriately and powerfully signified by a disintegration of poetic language ${ }^{47}$ affecting the time-honored notion of hermeneutic unity and baffling those readers and spectators of the play who have to grapple with a plurality of contradictory meanings and try to make sense of an enduring conflict of interpretations.

\section{Bibliography}

BLOOM Allan, "Richard II", in ALVIS John \& WEST Thomas (eds.), Shakespeare as Political Thinker, Durham: Carolina Academic Press, 1981, 51-61.

\footnotetext{
${ }^{43}$ Derek Traversi, Shakespeare from Richard II to Henry V, Stanford, CA: Stanford University Press, 1957, 29, 34, 48.

${ }^{44}$ Margaret Healy, William Shakespeare: Richard II, Plymouth: Northcote House Publishers Ltd, 1998, 31-48.

${ }^{45}$ John J. Joughin, "The Inauguration of Modern Subjectivity: Shakespeare's 'lyrical tragedy' Richard II', <www. e-rea. org>, consulted 9 July 2018, 22-34.

${ }^{46}$ Andrew Gurr, King Richard II, op. cit., 31, 34; Peter Ure, "The Looking-Glass of Richard II", PQ n 3, 1955, 219-24.

${ }^{47}$ Richard Wilson, "A Stringless Instrument': Richard II and the Defeat of Poetry", in Autour de Richard II de William Shakespeare, Arras: Artois Presses Université, 2005, 13-26. 
BROWNLOW Frank W., Two Shakespearean Sequences: "Henry VI" to "Richard II" and "Pericles" to "Timon of Athens", Pittsburgh: University of Pittsburgh Press, 1977.

COWAN Louise, "God Will Save the King: Shakespeare's Richard II', in ALVIS John \& WEST Thomas (eds.), Shakespeare as Political Thinker, Durham: Carolina Academic Press, 1981, 63-81.

CUBETA Paul M. (ed.), Twentieth Century Interpretations of Richard II, Englewood Cliffs, NJ: Prentice-Hall, Inc., 1971, 1-12.

DANBY John, Shakespeare's Doctrine of Nature: A Study of King Lear, London: Faber and Faber, 1949.

DEAN Leonard F., "From Richard II to Henry V: A Closer View", in CUBETA Paul M. (ed.), Twentieth Century Interpretations of Richard II, Englewood Cliffs, NJ: Prentice-Hall, 1971, 58-65.

DILLON Janette, Shakespeare and the Solitary Man, Totowa, NJ: Rowman \& Littlefield, 1981.

DUNCAN-JONES Katherine (ed.), Shakespeare's Sonnets, The Arden Shakespeare, London: Bloombury Methuen Drama, 2018.

EDWARDS Philip, "Person and Office in Shakespeare's Plays", Proceedings of the British Academy, $\mathrm{n}^{\circ}$ 56, 1970, 93-109.

FORKER Charles R. (ed.), King Richard II, The Arden Shakespeare, London: Thomson Learning, 2002.

GAUDET Paul, "The 'Parasitical' Counsellors in Shakespeare's Richard II: a Problem in Dramatic Interpretation", Shakespeare Quarterly, n 33, 1982, 142-54.

GODDARD Harold C., The Meaning of Shakespeare, 2 vol., Chicago and London: University of Chicago Press, 1960 [1951], vol. 1, 215-70.

GURR Andrew (ed.), King Richard II, The New Cambridge Shakespeare, Cambridge: Cambridge University Press, 1990 [1984].

GURR Andrew, "The Unbalanced Richard II", in Richard II de William Shakespeare. Une ouvre en contexte, Caen: Presses Universitaires de Caen, 2005, 57-69.

GURR Andrew (ed.), King Henry V, The New Cambridge Shakespeare, Cambridge: Cambridge University Press, 1992.

JOUGHIN John J., "The Inauguration of Modern Subjectivity: Shakespeare's 'lyrical tragedy' Richard II", <www. e-rea. org>, consulted 9 July 2018, 22-34.

HEALY Margaret, William Shakespeare: Richard II, Plymouth: Northcote House Publishers Ltd, 1998.

HOSLEY Richard (ed.), Shakespeare's Holinshed, New York: Capricorn Books, 1968.

KANTOROWICZ Ernst, The King's Two Bodies, Princeton, NJ: Princeton University Press, 1957.

KERNAN Alvin B, "The Henriad: Shakespeare's Major History Plays", in KERNAN Alvin B. (ed.), Modern Shakespearean Criticism. Essays on Style, Dramaturgy, and the Major Plays, New York: Harcourt, Brace \& World, Inc., 1970, 245-275.

LEGGATT Alexander, Shakespeare's Political Drama. The History Plays and the Roman Plays, London and New York: Routledge, 1988.

MARGESON John (ed.), King Henry VIII, The New Cambridge Shakespeare, Cambridge: Cambridge University Press, 1990.

PALMER John, "Richard of Bordeaux", in Political Characters of Shakespeare, London: Macmillan, 1945, 118179.

PORTER Joseph A., The Drama of Speech Acts: Shakespeare's Lancastrian Tetralogy, Berkeley, CA: University of California Press, 1979.

RIBNER Irving, "The Historical Richard”, in CUBETA Paul M. (ed.), Twentieth Century Interpretations of Richard II, Englewood Cliffs, NJ: Prentice-Hall, 1971, 13-14.

SMIDT Kristian, Unconformities in Shakespeare's History Plays, London: Macmillan, 1982.

STIRLING Brents, "Bolingbroke's 'decision”, Shakespeare Quarterly, n 2, 1951, 27-34.

STIRLING Brents, Unity in Shakespearean Tragedy. The Interplay of Theme and Character, New York: Columbia, 1956.

URE Peter (ed.), King Richard II, The Arden Shakespeare, London: Methuen, 1956.

URE Peter, "The Looking-Glass of Richard II", Philological Quarterly n² 2, 1955, 219-24.

TILLYARD E. M. W., Shakespeare's History Plays, Harmondsworth: Penguin Books Ltd, 1964 [1944].

TRAVERSI Derek, Shakespeare from Richard II to Henry V, Stanford, CA: Stanford University Press, 1957.

WEBBER Joan, "The Renewal of the King's Symbolic Role: From Richard II to Henry V', Texas Studies in Literature and Language $\mathrm{n}^{\circ} 4,1963,530-8$. 
WELLS Stanley (ed.), King Richard II, The New Penguin Shakespeare, Harmondsworth: Penguin Books Ltd, 1997 [1969].

WILSON Richard, “A Stringless Instrument': Richard II and the Defeat of Poetry”, in Autour de Richard II de William Shakespeare, Arras: Artois Presses Université, 2005, 13-26.

The Shattered Glass. Shakespeare's Richard II and the Crisis of Hermeneutics: this paper aims to question the premise that Shakespeare's Richard II is primarily concerned with the state of the polity and represents an ideological opposition between two conceptions of kingship. The political ambiguity of the confrontation, the static quality of the plot, and the portrayal of Richard's interiority are the defining features of a puzzling and enigmatic work which precludes a coherent interpretation of the antagonism of the rebel and the king's apathy. However, Shakespeare's use of the painter's perspective as a metaphor for cognition as well as illusion draws attention to a potential understanding of the play which transcends the misuse of kingly office and invites the audience to envisage Richard II as an anamorphic work that should be seen from the right edge so as to distinguish a meaningful form. Whereas the wrong point of view gives access to the literal meaning of the play, i.e. the deposing of a king by his adversary and the muddled responsibilities for the usurpation, the right way of looking resolves the deceitful perception of confusion into a clear pattern of transition from a medieval cognitive paradigm to a modern interpretive model. The entropic movement to modernity depicted in allegorical manner is dramatized by Shakespeare as a shift from a theological apprehension of Creation to an anthropocentric conception of the world and the place man occupies in it. The indiscriminate adoption of the latter perspective to view the historical disruption caused by the usurpation makes us blind to the emergence of a new set of norms which distort the image of the traditional order and discredit Richard's religious creed. By contrast, the change of hermeneutic paradigms inherent to the play presupposes a shift of perspectives in order to discern the revolutionary process which emancipates the present from the legacy of the past and results in the formation of autonomous communities, the substitution of ideology for theology and the fragmentation of social identities.

Le miroir brisé. Richard II de Shakespeare et la crise de l'herméneutique : cet article se propose d'examiner le présupposé selon lequel la pièce de Shakespeare aurait surtout un sens politique et représenterait l'opposition idéologique entre deux conceptions de la royauté. L'ambiguité politique de l'affrontement, le caractère statique de l'intrigue et l'intérêt pour l'intériorité de Richard sont les traits saillants d'une œuvre incompréhensible et énigmatique qui fait obstacle à une interprétation cohérente de l'antagonisme du rebelle comme de l'apathie du roi. L'emploi que fait Shakespeare de la perspective picturale comme métaphore de la connaissance et de l'illusion oriente l'attention vers une compréhension de la pièce dépassant la question de l'abus de pouvoir royal et invite les spectateurs à envisager Richard II comme une œuvre anamorphique devant être regardée selon un angle de vue adéquat pour distinguer une forme signifiante. Tandis que la vision erronée de l'œuvre permet d'appréhender son sens littéral, à savoir la destitution d'un roi par son adversaire et les responsabilités embrouillées de cette usurpation, la perspective ajustée à son objet transforme la perception trompeuse de confusion en une image distincte de la transition du paradigme médiéval de la connaissance au modèle protomoderne de l'interprétation. L'entropie à l'origine de la modernité est représentée allégoriquement par Shakespeare comme le remplacement d'une conception théologique de la Création par une lecture anthropocentrique du monde et de la place que l'homme y occupe. Adopter ce dernier point de vue sans discernement pour observer la rupture historique provoquée par l'usurpation nous rend aveugles à l'apparition de nouvelles normes dont la prise en compte entraîne la déformation de l'image de l'ordre traditionnel et le discrédit des croyances religieuses de Richard. En regard, le changement de paradigme herméneutique que représente la pièce suppose un déplacement du point de vue qui puisse faire apparaître le processus révolutionnaire à l'origine d'une émancipation du présent à l'égard de l'héritage du passé, ce bouleversement aboutissant à la formation de communautés autonomes, à la substitution de l'idéologie à la théologie et à la fragmentation des identités sociales. 